\title{
Association between central non-dipping pattern and platelets morphology in adults with type 1 diabetes without cardiovascular disease: a cross- sectional study
}

\section{Michal Kulecki ( $\square$ michal.kulecki@op.pl)}

Poznan University of Medical Sciences Faculty of Medicine I: Uniwersytet Medyczny imienia Karola Marcinkowskiego w Poznaniu Wydzial I Lekarski https://orcid.org/0000-0002-5224-6948

Dariusz Naskret

Poznan University of Medical Sciences: Uniwersytet Medyczny imienia Karola Marcinkowskiego w Poznaniu

\section{Mikolaj Kaminski}

Poznan University of Medical Sciences: Uniwersytet Medyczny imienia Karola Marcinkowskiego w

Poznaniu

\section{Dominika Kasprzak}

Poznan University of Medical Sciences: Uniwersytet Medyczny imienia Karola Marcinkowskiego w Poznaniu

\section{Pawel Lachowski}

Poznan University of Medical Sciences: Uniwersytet Medyczny imienia Karola Marcinkowskiego w Poznaniu

\section{Daria Klause}

Poznan University of Medical Sciences: Uniwersytet Medyczny imienia Karola Marcinkowskiego w Poznaniu

\section{Maria Kozlowska}

Poznan University of Medical Sciences: Uniwersytet Medyczny imienia Karola Marcinkowskiego w Poznaniu

\section{Aleksandra Uruska}

Poznan University of Medical Sciences: Uniwersytet Medyczny imienia Karola Marcinkowskiego w Poznaniu

\section{Dorota Zozulinska-Ziolkiewicz}

Poznan University of Medical Sciences: Uniwersytet Medyczny imienia Karola Marcinkowskiego w Poznaniu

\section{Justyna Flotynska}

Poznan University of Medical Sciences: Uniwersytet Medyczny imienia Karola Marcinkowskiego w Poznaniu 


\section{Original investigation}

Keywords: cardiovascular risk, dipping pattern, type 1 diabetes, mean platelet volume, platelet distribution width, hypertension

Posted Date: January 15th, 2021

DOl: https://doi.org/10.21203/rs.3.rs-144455/v1

License: (9) This work is licensed under a Creative Commons Attribution 4.0 International License. Read Full License 


\section{Abstract}

\section{Background}

People with type 1 diabetes mellitus (T1DM) have higher cardiovascular risk (CVR) compared to those from the general population. One of the markers of elevated CVR is a non-dipping pattern. Mean platelet volume (MPV) and platelet distribution width (PDW) are related to platelets' activation. Aortic systolic blood pressure (SBP Ao) has a better predictive value for cardiovascular disease than brachial systolic blood pressure (SBP Br). Hypertensives with non-dipping pattern have higher MPV than dippers. However, this relationship was never investigated among people with T1DM. This study aimed to investigate the association between central dipping pattern and platelets morphology in subjects with T1DM.

\section{Methods}

We measured SBPAo and SBPBr with a validated non-invasive brachial oscillometric device - Arteriograph 24 (TensioMed Ltd., Budapest, Hungary) - during twenty-four-hour analysis in T1DM subjects without diagnosed hypertension. The non-dipping pattern was defined as a nocturnal SBP Ao fall of less than $10 \%$. We collected medical history, anthropometrical features, and laboratory results. The group was divided based on the dipping pattern for dippers and non-dippers.

\section{Results}

From total 62 subjects (32 males) aged 30.1 (25.7-37) years with T1DM duration 15.0 (9.0-20) years, 36 were non-dippers based on SBP Ao. Non-dipper group had significantly higher MPV (10.4 [10-10.7] fl vs 10.9 [10.3-11.5] fl; $p=0.03$ ) and PDW (12.3 [11.7-12.8] fl vs 13.95 [11.7-15.1] fl; $p=0.02)$ than dipper group. The groups did not differ in classic risk factors. Multivariate logistic regression revealed that MPV (OR: $3.74 ; 95 \% \mathrm{Cl}=1.48-9.45 ; \mathrm{p}=0.005$ ) and daily insulin intake (OR: $445.11 ; 95 \% \mathrm{Cl}=4.25-46597.42 ; \mathrm{p}=$ 0.01 ) were independently positively associated with non-dipping pattern based on SBP Ao. PDW was also independently positively related to central non-dipping pattern (OR: $1.91 ; 95 \% \mathrm{Cl}=1.22-3.00 ; p=0.005$ ).

\section{Conclusions}

T1DM subjects with central non-dipping pattern have higher values of MPV and PDW than dippers. MPV and PDW are independently positively associated with SBP Ao non-dipping pattern among people with T1DM.

\section{Background}

Type 1 diabetes mellitus (T1DM) is a chronic metabolic illness, where insulin treatment is obligatory [1]. People with T1DM have a higher risk of developing cardiovascular disease than those from the general population [2]. Women with T1DM die 12.5 years earlier than women without diabetes. In the case of men, the difference is 11.6. years [3]. However, the pathophysiology of elevated cardiovascular risk in this population is still uncertain. 
The circadian rhythm of blood pressure (BP) is useful to predict cardiovascular events [4, 5]. The nondipping pattern is defined as nighttime systolic blood pressure (SBP) fall of less than $10 \%$ [6]. It is usually described based on brachial systolic blood pressure but central compared with brachial SBP is more strongly associated with preclinical organ damage [7]. Non-dippers have more cardiovascular events and higher cardiovascular mortality than dippers, even if they are normotensives [4].

Mean platelet volume (MPV) and platelet distribution width (PDW) are other possible cardiovascular risk markers. They describe platelet activation. Based on metanalysis (40 studies, 12285 individuals) subjects with coronary artery disease have higher MPV than healthy controls [8]. Higher values of MPV and PDW were significantly related to higher risks of cardiovascular disease [9]. MPV could predict longterm outcomes and cardiovascular events after the percutaneous coronary intervention [10]. The morphology and function of platelets in T1DM is disturbed [11,12]. Children with T1DM have significantly higher MPV and PDW than healthy controls [13].

Previous studies revealed the association between elevated MPV, PDW, and non-dipping pattern among people with hypertension [14-19]. However, a large study by Pusuroglu et al. [20] did not confirm that thus this relationship remains controversial. There is no data according to people without diagnosed hypertension. This association was never investigated in the T1DM population with a non-dipping pattern based on central SBP.

\section{Methods}

\section{Data collection}

The study aimed to investigate the association between central dipping pattern and platelets morphology in subjects with T1DM.

The participants of the study were under the control of the Department of Internal Medicine and Diabetology. We recruited them consecutively from February 2019 to March 2020. We included people aged between 18-45 years with T1DM confirmed in the past by positive antibodies, at least 5-year diabetes duration, and no less than $70 \%$ successful blood pressure measurements. The exclusion criteria were: cardiovascular disease, hypertension (or using antihypertensives), malignancy, chronic kidney disease (stages 2-5), sleep apnea, thrombocythemia, or thrombocytopenia. Each subject was asked to fill two forms, including diabetes duration, diabetic complications, drugs taken, coexisting diseases, and lifestyle.

Every participant underwent anamnesis and a standard physical examination. Specific investigations were performed to detect diabetic complications: retinopathy, neuropathy, and diabetic kidney disease. Besides, we repeated the brachial blood pressure measurement. The measurement was performed three times by an upper-arm manual sphygmomanometer on both hands after ten minutes of rest in the sitting position, at the level of the participant's heart. Basic anthropometric parameters (weight, height, waist, and hip circumferences) were measured. We calculated body mass index (BMI) and waist-to-hip ratio 
(WHR) using the following equations: $\mathrm{BMI}=$ weight $[\mathrm{kg}] /$ squared height $\left[\mathrm{m}^{2}\right] ;$ WHR $=$ waist circumference [cm]/ hip circumference [cm].

All blood samples were taken from participants in the morning, after an 8-12-hour overnight fast. They were drawn into standardized tubes with dipotassium ethylenedinitrotetraacetic acid (EDTA). The morphology of platelets was marked using an automatic blood counters (Sysmex XN1000 and Sysmex XN550, Sysmex Corporation Japan). MPV reflects the average size of platelets. PDW was counted from a platelet histogram at the level of $20 \%$ of the distribution peak. The same blood counters were used to mark the morphology of red blood cells and white blood cells.

We also obtained the following laboratory results: lipid profile, thyroid-stimulating hormone, creatinine, transaminases. Low-density lipoprotein cholesterol (LDL-C) level was estimated by the Friedewald formula [21]. Glycated hemoglobin (HbA1c) was evaluated with a turbidimetric inhibition immunoassay (Cobas 6000, Roche Diagnostics). Furthermore, the urine albumin to urine creatinine ratio (ACR) was calculated. Glucose Disposal Rate (eGDR) formula was chosen to calculate insulin resistance [22]: eGDR $[\mathrm{mg} / \mathrm{kg} / \mathrm{min}]=24.31-(12.22 \times$ WHR $)-(3.29 \times$ hypertension $)-(0.57 \times \mathrm{HbA1c})$ where: WHR - waist to hip ratio, hypertension - if present count as 1 , if not count as $0, \mathrm{HbA} 1 \mathrm{c}$ - glycated hemoglobin [\%].

Skin autofluorescence (which reflects advanced glycation end products accumulation and long-term diabetic control [23]) was measured using a non-invasive device (AGE-Reader, DiagnOptics BV, Groningen, The Netherlands). This method was validated by Meerwaldt et al. [24]

24-hour BP measurements were taken using Arteriograph 24 (TensioMed Ltd., Budapest, Hungary). We marked: aortic systolic blood pressure (SBP Ao), brachial systolic blood pressure (SBP Br), brachial diastolic blood pressure (DBP Br), and pulse. The operating principle of Arteriograph 24 is detecting and processing oscillations on the arm cuff by a special high-fidelity sensor during a complete occlusion of the brachial artery [25]. Arteriograph 24 was validated using invasive and non-invasive methods of AS assessment $[25,26]$.

An appropriate cuff was chosen based on arm circumference. We measured the distance from the jugular notch to the pubic symphysis in the supine position to estimate the length of the aorta (required to calculate PWV).

We used TensioWin software to program Arteriograph 24. Measurements were taken every 30 minutes daily and every 1 hour nightly for 24 hours. Participants were instructed to start manual measurement in case of failed automatic measurement. After 24 hours, the device was removed, and the results were transferred to our database.

Each participant was asked to fill another questionnaire concerning hour by hour activity during 24 hours of measurement, including physical activity, number of cigarettes, number of (caffeine-containing) coffee cups, body position in the moment of measurement, glycemia (at least 5 measurements per day), and insulin dosages. We also marked the time of sleeping. 
Subjects with a nighttime SBP fall of less than $10 \%$ were included in the group of non-dippers. Entities with the nighttime SBP fall of at least $10 \%$ were involved in the group of dippers.

\section{Data analysis}

R-programming language (version 3.6.1.; Vienna, R Project) was used for statistical analysis. The data is presented either as number and percentage (categorical) or while as a median and interquartile range (numerical). We used the Chi-square and the Mann-Whitney $U$ tests to compare dippers and non-dippers based on central and brachial SBP. P-value was set as two-sided.

We performed a logistic regression analysis. The dependent variable was the presence of a central or brachial non-dipping pattern. All variables independent of BP were chosen for univariate regression analysis. Univariate regression results with $p<0.1$ and other known non-dipping pattern risk factors were included in multivariate regression analysis [27]. PDW was included in another model because it was highly positively associated with MPV. We also excluded some variables because of the collinearity.

\section{Results}

80 participants were recruited. However, we finally included 62 subjects in the final analysis. The scheme of the study is presented in Figure 1.The participants were aged 30.1 (25.7-37) years, 32 (51.6\%) of them were males. The median T1DM duration was 15.0 (9.0-20.0) years. 36 (58.1\%) were non-dippers based on SBP Ao; 25 (40.3\%) were non-dippers based on SBP Br.

The groups (non-dippers vs dippers based on central SBP) did not differ significantly in general characteristics, diabetes complications, methods of treatment and activity during the day of measurement. Non-dipper group had significantly higher MPV (10.9 [10.3-11.5] vs 10.4 [10-10.7] fl; $p=$ 0.03 ) and PDW (13.95 [11.7-15.1] vs 12.3 [11.7-12.8] fl; $p=0.02)$ than dipper group. Non-dippers consumed more alcohol than dippers (1.5 [0.0-4.0] vs 0.8 [0.0-1.0] units/week; $p=0.015)$. Results are presented in Table 1. In univariate regression analysis (dependent variable - presence of SBP Ao nondipping pattern) MPV, PDW sex, height, potassium, daily insulin intake and alanine aminotransferase were significant $(p<0.1)$. Multivariate logistic regression revealed that MPV (OR: $3.94 ; 95 \% \mathrm{Cl}=1.45$ $10.72 ; p=0.007)$ and daily insulin intake (OR: 253.23; $95 \% \mathrm{Cl}=2.99-21420.55 ; p=0.01$ ) were independently positively associated with non-dipping pattern based on SBP Ao (Figure 2). The model with PDW showed the independent, positive relationship between PDW (OR: 1.91; 95\% $\mathrm{Cl}=1.22-3.00$; $p=0.005)$, daily insulin intake (OR: $445.11 ; 95 \% \mathrm{Cl}=4.25-46597.42 ; p=0.01)$ and central non-dipping pattern (figure 3).

The comparison of non-dippers and dippers based on brachial SBP revealed the difference in PDW which was higher in the non-dipper group - (13.9 [12.1-15.1] vs 12.3 [11.7-13.4] fl; $p=0.020)$ but not in MPV (10.7 [10.3-11.4] vs 10.4 [10.0-10.9] p = 0.11). In SBP Br non-dipper group were significantly more males than in dipper group (17 [68.0\%] vs 15 [40.5\%] p = 0.034) (table 2). In univariate regression analysis (dependent variable - presence of SBP br non-dipping pattern) PDW, sex and height were significant ( $p<$ 
0.1) Multivariate logistic regression revealed that only MPV (OR: $2.50 ; 95 \% \mathrm{Cl}=1.09-5.71 ; \mathrm{p}=0.008)$ and PDW in another model (OR: 1.69; $95 \% \mathrm{Cl}=1.15-2.49 ; \mathrm{p}=0.008)$ were independently positively associated with non-dipping pattern based on SBP Br (Figures 4 and 5).

All of our participants had no diagnosed hypertension but $61.3 \%$ of them had elevated BP values in 24hour measurement. Therefore, we performed an additional analysis for participants without hypertension in 24-hour measurement. SBP Ao non dippers had significantly higher MPV (11.0 [10.5-11.6] vs 10.5 $[10.0-10.7] \mathrm{fl} ; \mathrm{p}=0,026)$ and PDW (14.0 [12.5-15.1] vs $12.0[11.7-12.6] \mathrm{fl} ; \mathrm{p}=0,035)$ (table 3).

\section{Discussion}

\section{Main Findings}

To our knowledge, this is the first study investigating the relationship between platelets morphology and central non-dipping pattern in the T1DM population. We found that MPV and PDW were significantly higher in central non-dippers compared to dippers among people with T1DM. MPV and PDW were independently positively associated with the presence of a central non-dipping pattern.

There are different methods to assess platelet reactivity, but many of them are complicated and highpriced [28]. The alternative is MPV, an indirect method of platelet activity measurement. It correlates with platelet aggregation markers, which are easy to perform and cost-effective [29]. Higher MPV correlates to a higher number of dense bodies per platelet, LDH activity, speed of ADP-induced aggregation, serotonin uptake, and release [30]. However, many other factors could influence MPV: genetic variants, race, ethnicity, age, sex, and lifestyle [31].

It is known that hypertension relates to a hypercoagulable state, resulting from increased platelet activity. Hypertensives have higher MPV and higher quantity of P-selectin and beta-thromboglobulin normotensives. These proteins take part in platelet activation [32]. Gang et al. in a prospective study with a 9-years follow-up proved that elevated MPV allows predicting the development of hypertension independently of other risk factors like age, gender, and SBP [33]. Prehypertension is also associated with higher MPV [34].

Chinese prospective study in a large group of 31751 people revealed that higher values of MPV were associated with a higher risk of stroke, cardiovascular disease, and coronary heart disease after six years of follow-up. Higher PDW was related to a higher risk of cardiovascular disease and coronary heart disease [9]. Higher MPV is also associated with a higher risk of restenosis after percutaneous transluminal coronary angioplasty [10].

Both non-dipping pattern and increased MPV are associated with elevated cardiovascular risk [5, 35]. However, the pathophysiology of the relationship between the non-dipping pattern and MPV is unknown. The non-dipping pattern is related to higher nighttime SBP and the same higher mean diurnal SBP. Increased BP may lead to endothelium damage which results in elevated shear stress, an imbalance 
between free radicals and antioxidants, platelet activation, and aggregation [36]. Another possible pathomechanism is the impairment of the autonomic nervous system - low parasympathetic and high sympathetic activity. Catecholamines may stimulate alpha-2 adrenoreceptors which induce platelet aggregation [37]. This theory also suggests that adrenaline causes the release of the large activated platelets sequestered in the spleen [38].

It is known that the presence of diabetes is associated with increased platelet activity. Shimodaira et al proved that MPV was positively, independently related to fasting plasma glucose among both individuals with prediabetes and healthy people with normal glucose levels [39]. In children with T1DM MPV was related to aortic intima-media thickness which is an early indicator of subclinical atherosclerosis [40]. Abdel-Moneim et al compared three groups of children: with established T1DM (duration: 0.66 0.4 years), with newly-diagnosed T1DM (duration: $0.66 \pm 0.4$ years), and healthy controls. MPV and PDW were significantly higher in children with T1DM than those in the control group [41]. Platelet number was lower in children with established T1DM than in children with the newly diagnosed disease and controls. MPV was related to $\mathrm{HbA1C}$ among people with T1DM as opposed to T2DM subjects [11]. Children with HbA1C $\leq 7.5 \%$ had significantly higher MPV and PDW than children with $\mathrm{HbA} 1 \mathrm{C}$ below $7.5 \%$. MPV was positively correlated with T1DM duration [12].

The relationship between platelets morphology and dipping pattern among T1DM subjects is uninvestigated. Our study is the first one and revealed the need for further research. Nevertheless, there are some works focused on dipping pattern in this population. Theilade et al investigated for the first time the central dipping among subjects with T1DM [42]. They proved that nocturnal central and brachial SBP fall decreased with diabetes duration and albuminuria. There was an association between $\mathrm{HbA} 1 \mathrm{C}$ and non-dipping pattern [43]. However, Mamta et al observed no relationship between brachial non-dipping pattern and glucose variability in subjects with T1DM [44]. Another study showed that nephropathy (but not other diabetic complications) was independently associated with a brachial non-dipping pattern [45]. Spallone et al suggested the role of autonomic neuropathy in the development of nephropathy and nondipping pattern in T1DM subjects, but further studies did not confirm that relationship [46, 47]. In our study, we did not observe such associations. The groups did not differ in long-term diabetic control (HbA1C, skin autofluorescence), presence of diabetic complications, and insulin resistance (eGDR). However, the central non-dipping pattern was independently, positively related to daily insulin intake. The whole study group was relatively young and had a low level of albumin to creatine ratio. It suggests that the non-dipping pattern may develop independently of glycemic control.

The prevalence of non-dipping pattern among people with T1DM is uninvestigated because few studies have been published on this topic. It was noted by Jaiswal et al. [44]. In their study, the prevalence of nondipping pattern in 41 T1DM subjects was only $10 \%$. A previous study by Stella et al showed that $27,8 \%$ of 61 T1DM entities were non-dippers [45]. The prevalence was 40,3\% for the brachial non-dipping pattern and $58.1 \%$ for the central non-dipping pattern in our study. 
In the literature, several works describe the association between MPV and non-dipping pattern, but all of them are based only on brachial BP. MPV is thought to be higher in non-dippers than dippers among people with hypertension treated at least 6 months [14]. Inanc et al. demonstrated that non-dippers have higher MPV than dippers and normotensives [15]. Other studies confirmed the positive relationship between MPV and non-dipping patterns among hypertensives $[16,17,48]$. A similar finding was obtained among hypertensive children, people with uncontrolled hypertension, and prehypertensive non-smokers $[18,49]$. Meric et al. observed that the mean platelet volume/ platelet count (MPV/PC) ratio was significantly higher in non-dippers than dippers and it could be used to predict non-dipping pattern with 95 sensitivity and 95 specificity [19]. In our study MPV was higher in central non-dippers than dippers. There were no significant differences in MPV based on the brachial dipping pattern. However, MPV was independently associated with a brachial non-dipping pattern in the multivariate regression model. We found no association between dipping pattern and MPV/PC ratio.

Previously described studies were performed in relatively small populations. On the contrary, Pusuroglu et al. found no difference in MPV between hypertensive dippers and non-dippers in the group of 840 participants [50]. However, MPV was significantly higher in hypertensives compared to normotensives. The non-dipping pattern was diagnosed only in hypertensives, so there was no information on how many subjects without hypertension were non-dippers. We included only subjects with T1DM and without diagnosed hypertension. In our study group, there was no difference in MPV between dippers and nondippers based on peripheral BP, but MPV was significantly higher in central BP non-dippers than dippers. Further studies are needed to confirm if MPV is more strongly associated with central than brachial dipping.

In our study, we excluded people with alcoholism. However, non-dippers consumed significantly more standard units of alcohol per week than dippers. Even small amounts of alcohol may be associated with the non-dipping pattern but because of the cross-sectional character of our study, we cannot find any cause and effect relationships.

\section{Strengths and practical implications}

We proved for the first time the relationship between non-dipping pattern and MPV among people with T1DM. Moreover, this is the first study investigating not only the brachial but central non-dipping pattern and its association with platelets morphology. Several studies proved that brachial non-dippers have higher MPV than dippers. We also showed that PDW (which was not investigated earlier) is higher in people without appropriate nocturnal fall in BP.

Those results bring practical implications because people with non-dipping pattern and increased platelet activity have elevated cardiovascular risk. Thanks to 24-hour BP measurement, PDW, and MPV, it is possible to identify them. We know that in non-dippers increased platelet activity should be suspected. These people should be watchfully observed. Non-pharmacological treatment could be useful because 20-weeks lifestyle modification (decreased sodium intake, intensified physical activity, reduction of alcohol consumption, and DASH diet) may reduce MPV in prehypertensive subjects [51]. Aspirin and other 
antiplatelet drugs are not recommended in primary prevention among T1DM subjects with low or moderate cardiovascular risk [52]. According to the ASCEND study, aspirin brings more side effects than benefits, in primary cardiovascular prevention among people with diabetes [53]. However, this data is based mostly on subjects with type 2 diabetes mellitus and the topic remains controversial. People with diabetes with non-dipping pattern and increased platelet activity may have benefits from using antiplatelet drugs. Further studies are needed to establish proper treatment for T1DM subjects with a nondipping pattern.

\section{Limitations}

Our study has some limitations. We did not measure cardiac autonomic neuropathy, which could influence on dipping pattern. However, studies did not confirm the relationship between non-dipping pattern and autonomic neuropathy [47]. We used MPV and PDW as indirect markers of platelet activity and we did not perform more complicated, direct methods of platelet activity assessment. Each participant had only one day of 24-hour BP measurement.

\section{Conclusions}

Type 1 diabetes subjects with central non-dipping pattern have higher values of MPV and PDW than dippers. MPV and PDW are independently positively associated with the central non-dipping pattern.

\section{Abbreviations}

$\mathrm{BP}$ - blood pressure

$\mathrm{DBP} \mathrm{Br}$ - brachial diastolic blood pressure

eGDR - estimated Glucose Disposal Rate

HbA1C - glycated hemoglobin

LDL-C - Low-density lipoprotein cholesterol

MPV - mean platelet volume

NAFLD - non-alcoholic liver disease

PDW - platelet distribution width

SBP - systolic blood pressure

SBP Ao - aortic systolic blood pressure

SBP Br - brachial systolic blood pressure 
T1DM - type 1 diabetes mellitus

WHR - waist-to-hip ratio

\section{Declarations}

\section{Ethics approval and consent to participate}

The data comes from the Poznań Atherosclerosis in Adult Patients with long-term Type 1 Diabetes Mellitus Study (PARADISE T1DM Study), which was conducted according to the decision of the local Ethics Committee (approval No. 67/19). The study complies with the Declaration of Helsinki. In all cases, we obtained written informed consent before inclusion in the study.

\section{Consent for publication}

Not applicable.

\section{Availability of data and materials}

The datasets analyzed during the current study are available from the corresponding author on reasonable request.

\section{Competing interests}

The authors declare that they have no competing interests.

\section{Funding}

This work was supported by the Poznan University of Medical Sciences [grant numbers: 3551].

\section{Authors' contributions}

MKul: Conceptualization, Methodology, Formal analysis, Investigation, Resources, Data curation, Methodology, Original draft; DN: Project administration, Supervision, Conceptualization, Review and editing, Investigation, Resources; MKam: Formal analysis, Supervision, Review and editing, Investigation, Resources; DKasp: Review and editing, Investigation, Resources; PL: Investigation, Resources, DKla: Investigation, Resources, Design of the work; MKoz: Investigation, Resources, Design of the work; AU: Supervision, Review and editing, Project administration; DZZ: Supervision, Review and editing; JF: Resources, Design of the work;

\section{Acknowledgments}

Not applicable.

\section{References}


1. Association AD (2020) Standards of Medical Care in Diabetes-2020 Abridged for Primary Care Providers. Clinical Diabetes 38:10-38

2. Schofield J, Ho J, Soran H (2019) Cardiovascular Risk in Type 1 Diabetes Mellitus. Diabetes Ther 10:773-789

3. Huo L, Harding JL, Peeters A, Shaw JE, Magliano DJ (2016) Life expectancy of type 1 diabetic patients during 1997-2010: a national Australian registry-based cohort study. Diabetologia 59:1177-1185

4. Ohkubo T, Hozawa A, Yamaguchi J, et al (2002) Prognostic significance of the nocturnal decline in blood pressure in individuals with and without high 24-h blood pressure: the Ohasama study. $J$ Hypertens 20:2183-2189

5. Ohkubo T, Imai Y, Tsuji I, et al (1997) Relation between nocturnal decline in blood pressure and mortality. The Ohasama Study. Am J Hypertens 10:1201-1207

6. Williams B, Mancia G, Spiering W, et al (2018) 2018 ESC/ESH Guidelines for the management of arterial hypertensionThe Task Force for the management of arterial hypertension of the European Society of Cardiology (ESC) and the European Society of Hypertension (ESH). Eur Heart J 39:30213104

7. Kollias A, Lagou S, Zeniodi ME, Boubouchairopoulou N, Stergiou GS (2016) Association of Central Versus Brachial Blood Pressure With Target-Organ Damage: Systematic Review and Meta-Analysis. Hypertension 67:183-190

8. Sansanayudh N, Anothaisintawee T, Muntham D, McEvoy M, Attia J, Thakkinstian A, (2014) Mean platelet volume and coronary artery disease: a systematic review and meta-analysis. Int $\mathrm{J}$ Cardiol 175:433-440

9. He S, Lei W, Li J, et al (2019) Relation of Platelet Parameters With Incident Cardiovascular Disease (The Dongfeng-Tongji Cohort Study). American Journal of Cardiology 123:239-248

10. Yang A, Pizzulli L, Lüderitz B (2006) Mean platelet volume as marker of restenosis after percutaneous transluminal coronary angioplasty in patients with stable and unstable angina pectoris. Thromb Res 117:371-377

11. Zaccardi F, Rocca B, Rizzi A, Ciminello A, Teofili L, Ghirlanda G, De Stefano V, Pitocco D (2017) Platelet indices and glucose control in type 1 and type 2 diabetes mellitus: A case-control study. Nutr Metab Cardiovasc Dis 27:902-909

12. Venkatesh V, Kumar R, Varma DK, Bhatia P, Yadav J, Dayal D (2018) Changes in platelet morphology indices in relation to duration of disease and glycemic control in children with type 1 diabetes mellitus. J Diabetes Complicat 32:833-838

13. Malachowska B, Tomasik B, Szadkowska A, Baranowska-Jazwiecka A, Wegner O, Mlynarski W, Fendler W (2015) Altered Platelets' morphological parameters in children with type 1 diabetes - a case-control study. BMC Endocr Disord. https://doi.org/10.1186/s12902-015-0011-8

14. Ordu S, Ozhan H, Caglar O, Alemdar R, Basar C, Yazici M, Erden I (2010) Mean platelet volume in patients with dipper and non-dipper hypertension. Blood Press 19:26-30 
15. Inanc T, Kaya MG, Yarlioglues M, et al (2010) The mean platelet volume in patients with non-dipper hypertension compared to dippers and normotensives. Blood Press 19:81-85

16. Kaya MG, Yarlioglues M, Gunebakmaz O, Gunturk E, Inanc T, Dogan A, Kalay N, Topsakal R (2010) Platelet activation and inflammatory response in patients with non-dipper hypertension. Atherosclerosis 209:278-282

17. Surgit O, Erturk M, Akgul O, Pusuroglu H, Korkmaz AF, Isiksacan N, Gul M, Uzun F, Ozal E, Eksik A (2015) Assessment of mean platelet volume and soluble CD40 ligand levels in patients with nondipper hypertension, dippers and normotensives. Clin Exp Hypertens 37:70-74

18. Erdogan D, Icli A, Aksoy F, Akcay S, Ozaydin M, Ersoy I, Varol E, Dogan A (2013) Relationships of different blood pressure categories to indices of inflammation and platelet activity in sustained hypertensive patients with uncontrolled office blood pressure. Chronobiol Int 30:973-980

19. Meric M, Yuksel S, Coksevim M, Gulel O (2019) The Effect of Mean Platelet Volume/Platelet Count Ratio on Dipper and Non-Dipper Blood Pressure Status. Medicina (Kaunas) 55:

20. Pusuroglu H, Cakmak HA, Erturk M, Akgul O, Akkaya E, Tosu AR, Celik O, Gul M, Yildirim A (2014) Assessment of the relation between mean platelet volume, non-dipping blood pressure pattern, and left ventricular mass index in sustained hypertension. Med Sci Monit 20:2020-2026

21. Cordova CMM de, Schneider CR, Juttel ID, Cordova MM de (2004) Comparison of LDL-cholesterol direct measurement with the estimate using the Friedewald formula in a sample of 10,664 patients. Arquivos Brasileiros de Cardiologia 83:476-481

22. Williams KV, Erbey JR, Becker D, Arslanian S, Orchard TJ (2000) Can clinical factors estimate insulin resistance in type 1 diabetes? Diabetes 49:626-632

23. Sugisawa E, Miura J, Iwamoto Y, Uchigata Y (2013) Skin autofluorescence reflects integration of past long-term glycemic control in patients with type 1 diabetes. Diabetes Care 36:2339-2345

24. Meerwaldt R, Graaff R, Oomen PHN, Links TP, Jager JJ, Alderson NL, Thorpe SR, Baynes JW, Gans ROB, Smit AJ (2004) Simple non-invasive assessment of advanced glycation endproduct accumulation. Diabetologia 47:1324-1330

25. Baulmann J, Schillings U, Rickert S, Uen S, Düsing R, Illyes M, Cziraki A, Nickering G, Mengden T (2008) A new oscillometric method for assessment of arterial stiffness: comparison with tonometric and piezo-electronic methods. J Hypertens 26:523-528

26. Horváth IG, Németh A, Lenkey Z, Alessandri N, Tufano F, Kis P, Gaszner B, Cziráki A (2010) Invasive validation of a new oscillometric device (Arteriograph) for measuring augmentation index, central blood pressure and aortic pulse wave velocity. J Hypertens 28:2068-2075

27. de la Sierra A, Redon J, Banegas JR, et al (2009) Prevalence and factors associated with circadian blood pressure patterns in hypertensive patients. Hypertension 53:466-472

28. Michelson AD (2009) Methods for the measurement of platelet function. Am J Cardiol 103:20A-26A

29. Khaspekova SG, Ziuriaev IT, lakushkin VV, Naĭmushin IA, Sirotkina OV, Zaĭtseva NO, Ruda MI, Mazurov AV (2014) [Mean platelet volume: interactions with platelet aggregation activity and glycoprotein Ilb-Illa and Ib expression levels]. Biomed Khim 60:94-108 
30. Thompson CB, Eaton KA, Princiotta SM, Rushin CA, Valeri CR (1982) Size dependent platelet subpopulations: relationship of platelet volume to ultrastructure, enzymatic activity, and function. $\mathrm{Br}$ J Haematol 50:509-519

31. Korniluk A, Koper-Lenkiewicz OM, Kamińska J, Kemona H, Dymicka-Piekarska V (2019) Mean Platelet Volume (MPV): New Perspectives for an Old Marker in the Course and Prognosis of Inflammatory Conditions. Mediators of Inflammation 2019:e9213074

32. Nadar SK, Blann AD, Kamath S, Beevers DG, Lip GYH (2004) Platelet indexes in relation to target organ damage in high-risk hypertensive patients: a substudy of the Anglo-Scandinavian Cardiac Outcomes Trial (ASCOT). J Am Coll Cardiol 44:415-422

33. Gang L, Yanyan Z, Zhongwei Z, Juan D (2017) Association between mean platelet volume and hypertension incidence. Hypertens Res 40:779-784

34. Yuksel C, Celik T, Demirkol S, Celik M, Bugan B, lyisoy A, Yaman H (2011) Increased platelet activation in young patients with prehypertension. Clin Exp Hypertens 33:381-387

35. Chu SG, Becker RC, Berger PB, Bhatt DL, Eikelboom JW, Konkle B, Mohler ER, Reilly MP, Berger JS (2010) Mean platelet volume as a predictor of cardiovascular risk: a systematic review and metaanalysis. J Thromb Haemost 8:148-156

36. Blann AD, Nadar S, Lip GYH (2003) Pharmacological modulation of platelet function in hypertension. Hypertension 42:1-7

37. Siess W, Lapetina EG (1989) Platelet aggregation induced by alpha 2-adrenoceptor and protein kinase $C$ activation. A novel synergism. Biochem J 263:377-385

38. Sherwood A, Steffen PR, Blumenthal JA, Kuhn C, Hinderliter AL (2002) Nighttime blood pressure dipping: the role of the sympathetic nervous system. Am J Hypertens 15:111-118

39. Shimodaira M, Niwa T, Nakajima K, Kobayashi M, Hanyu N, Nakayama T (2013) Correlation between mean platelet volume and fasting plasma glucose levels in prediabetic and normoglycemic individuals. Cardiovascular Diabetology 12:14

40. Ersoy M, Selcuk Duru HN, Elevli M, Ersoy O, Civilibal M (2015) Aortic Intima-Media Thickness and Mean Platelet Volume in Children with Type 1 Diabetes Mellitus. Iran J Pediatr. https://doi.org/10.5812/ijp.368

41. Abdel-Moneim A, Zanaty MI, El-Sayed A, Khalil RG, Rahman HA (2020) Relation Between Oxidative Stress and Hematologic Abnormalities in Children with Type 1 Diabetes. Can J Diabetes 44:222-228

42. Theilade S, Lajer M, Joergensen C, Persson F, Andresdottir G, Reinhard H, Nielsen S, Lacy P, Williams B, Rossing P (2012) 67 FIRST EVER 24-HOUR CENTRAL BLOOD PRESSURE IN PATIENTS WITH TYPE 1 DIABETES. Journal of Hypertension 30:e21

43. Vílchez-López FJ, Carral-Sanlaureano F, Coserria-Sánchez C, Nieto A, Jiménez S, Aguilar-Diosdado M (2011) Alterations in arterial pressure in patients with Type 1 diabetes are associated with long-term poor metabolic control and a more atherogenic lipid profile. J Endocrinol Invest 34:e24-29

44. Mamta J, Lynn A, Kara M-S, Rodica P-B (2018) Is there an association between non-dipping blood pressure and measures of glucose variability in type 1 diabetes? J Diabetes Complications 32:947- 
950

45. Stella P, Tabak AG, Zgibor JC, Orchard TJ (2006) Late diabetes complications and non-dipping phenomenon in patients with Type 1 diabetes. Diabetes Res Clin Pract 71:14-20

46. Spallone V, Gambardella S, Maiello MR, Barini A, Frontoni S, Menzinger G (1994) Relationship between autonomic neuropathy, 24-h blood pressure profile, and nephropathy in normotensive IDDM patients. Diabetes Care 17:578-584

47. Stella P, Tabak AG, Zgibor JC, Orchard TJ (2006) Late diabetes complications and non-dipping phenomenon in patients with Type 1 diabetes. Diabetes Res Clin Pract 71:14-20

48. Yildiz G, Hür E, Özçiçek A, Candan F, Kayatas M (2013) The mean platelet volume and atherogenic index of plasma in nondipper normotensive individuals compared to dippers. Clin Exp Hypertens 35:35-39

49. Taban Sadeghi M, Soroureddin Z, Nouri-Vaskeh M, Nazarpoori P, Aghayari Sheikh Neshin S (2019) Association of the mean platelet volume and red cell distribution width with dipper and non-dipper blood pressure in prehypertensive non-smokers. BMC Research Notes 12:824

50. Pusuroglu H, Cakmak HA, Erturk M, Akgul O, Akkaya E, Tosu AR, Celik O, Gul M, Yildirim A (2014) Assessment of the relation between mean platelet volume, non-dipping blood pressure pattern, and left ventricular mass index in sustained hypertension. Med Sci Monit 20:2020-2026

51. Yazici M, Kaya A, Kaya Y, Albayrak S, Cinemre H, Ozhan H (2009) Lifestyle modification decreases the mean platelet volume in prehypertensive patients. Platelets 20:58-63

52. Cosentino F, Grant PJ, Aboyans V, et al (2020) 2019 ESC Guidelines on diabetes, pre-diabetes, and cardiovascular diseases developed in collaboration with the EASDThe Task Force for diabetes, prediabetes, and cardiovascular diseases of the European Society of Cardiology (ESC) and the European Association for the Study of Diabetes (EASD). Eur Heart J 41:255-323

53. (2018) Effects of Aspirin for Primary Prevention in Persons with Diabetes Mellitus. New England Journal of Medicine 379:1529-1539

\section{Tables}

Table 1. Comparison of groups with and without central non-dipping pattern according to the Arteriograph 24 results. 


\begin{tabular}{|c|c|c|c|c|}
\hline & $\begin{array}{l}\text { All } \\
\text { participants }\end{array}$ & $\begin{array}{l}\text { SBP Ao } \\
\text { dippers }\end{array}$ & $\begin{array}{l}\text { SBP Ao non- } \\
\text { dippers }\end{array}$ & $\mathrm{p}$-value \\
\hline & $\begin{array}{l}n=62 \\
(100 \%)\end{array}$ & $\begin{array}{l}n=26 \\
(41.9 \%)\end{array}$ & $\begin{array}{l}n=36 \\
(58.1 \%)\end{array}$ & \\
\hline \multicolumn{5}{|l|}{ General characteristics } \\
\hline Males n (\%) & $32(51.6 \%)$ & $10(38.5 \%)$ & $22(61.1 \%)$ & 0.08 \\
\hline Age [years] & $\begin{array}{l}30.1(25.7- \\
37.0)\end{array}$ & $\begin{array}{l}29.6(22.3- \\
39.4)\end{array}$ & $\begin{array}{l}32.8(27.5 \\
-36.8)\end{array}$ & 0.59 \\
\hline Diabetes duration [years] & $\begin{array}{l}15.0(9.0- \\
20.0)\end{array}$ & $\begin{array}{l}16.0(9.0- \\
22.0)\end{array}$ & $\begin{array}{l}15.0(8.5- \\
18.5)\end{array}$ & 0.43 \\
\hline BMI $\left[\mathrm{kg} / \mathrm{m}^{2}\right]$ & $\begin{array}{l}24.8(22.7- \\
28.2)\end{array}$ & $\begin{array}{l}25.9(23.2- \\
28.7)\end{array}$ & $\begin{array}{l}24.3(22.1- \\
28.2)\end{array}$ & 0.31 \\
\hline WHR & $0.9(0.8-0.9)$ & $0.9(0.8-0.9)$ & $0.9(0.8-0.9)$ & 0.92 \\
\hline Family history for CVD n (\%) & $17(27.4 \%)$ & $5(19.2 \%)$ & $12(33.3 \%)$ & 0.22 \\
\hline $\begin{array}{l}\text { Systolic blood pressure } \\
\text { [mmHg] }\end{array}$ & $\begin{array}{l}123.0(120.0- \\
131.0)\end{array}$ & $\begin{array}{l}123.0 \\
(116.0- \\
131.0)\end{array}$ & $\begin{array}{l}123.0(120.0- \\
132.0)\end{array}$ & 0.84 \\
\hline $\begin{array}{l}\text { Diastolic blood pressure } \\
\text { [mmHg] }\end{array}$ & $\begin{array}{l}80.0(76.0- \\
86.0)\end{array}$ & $\begin{array}{l}80.0(76.0- \\
85.0)\end{array}$ & $\begin{array}{l}81.0(77.0- \\
86.5)\end{array}$ & 0.43 \\
\hline \multicolumn{5}{|l|}{ Lifestyle } \\
\hline Current smoker n (\%) & $15(24.2 \%)$ & $6(23.1 \%)$ & $9(25 \%)$ & 0.86 \\
\hline Packyears & $\begin{array}{l}0.0(0.0 \\
-68.0)\end{array}$ & $\begin{array}{l}0.0(0.0- \\
40.0)\end{array}$ & $\begin{array}{l}2.3(0.0- \\
95.0)\end{array}$ & 0.28 \\
\hline Sport activity [hours/week] & $2.4(0.0-6.0)$ & $2.0(1.0-7.0)$ & $3.0(0.0-6.0)$ & 0.86 \\
\hline Alcohol intake [units/week] & $1.0(\underline{0.0-2.0})$. & $\underline{0.8}(\underline{0.0-1.0})$. & $\underline{1.5}(\underline{0.0-4.0})$. & $\underline{0.015}$ \\
\hline Shift work n (\%) & $22(35.5 \%)$ & $10.0(38.5 \%)$ & $12.0(33.3 \%)$ & 0.68 \\
\hline Sleeping [hours/day] & $7.0(6.0-8.0)$ & $7.0(6.0-8.0)$ & $7.0(6.0-8.0)$ & 0.90 \\
\hline Physical work [hours/day] & $3.0(0.0-8.0)$ & $2.0(0.0-8.0)$ & $3.0(0.0-8.0)$ & 0.51 \\
\hline \multicolumn{5}{|l|}{ Complications } \\
\hline $\begin{array}{l}\text { At least one diabetic } \\
\text { complication } \mathrm{n}(\%)\end{array}$ & $34(54.8 \%)$ & $13(50 \%)$ & $21(58.3 \%)$ & 0.52 \\
\hline Diabetic retinopathy n (\%) & $12(19.4 \%)$ & $4(15.4 \%)$ & $8(22.2 \%)$ & 0.50 \\
\hline Diabetic nephropathy n (\%) & $2(3.2 \%)$ & $1(3.8 \%)$ & $1(2.8 \%)$ & 0.81 \\
\hline Diabetic neuropathy n (\%) & $28(45.2 \%)$ & $13(50 \%)$ & $15(41.7 \%)$ & 0.52 \\
\hline
\end{tabular}




\begin{tabular}{|lllll}
\hline Treatment & & & \\
\hline Insulin pump n (\%) & $25(40.3 \%)$ & $10(38.5 \%)$ & $15(41.7 \%)$ & 0.95 \\
$\begin{array}{l}\text { Daily insulin intake [insulin } \\
\text { units/day/kg] }\end{array}$ & $0.6(0.5-0.7)$ & $0.6(0.5-0.6)$ & $0.6(0.5-0.8)$ & 0.09 \\
\hline Metformin n (\%) & $6(9.7 \%)$ & $2(7.7 \%)$ & $4(11.1 \%)$ & 0.65 \\
\hline Lipid profile & & & & \\
\hline Triglycerides [mmol/l] & $1.0(0.7-1.3)$ & $1.0(0.7-1.4)$ & $0.9(0.6-1.3)$ & 0.61 \\
\hline Total cholesterol [mmol/l] & $4.6(4.2-5.1)$ & $4.6(4.2-5.1)$ & $4.4(4.2-5.2)$ & 0.95 \\
\hline LDL-C [[mmol/l] & $2.4(2.0-2.8)$ & $2.4(2.0-2.8)$ & $2.4(2.0-3.1)$ & 0.89 \\
\hline HDL-C [mmol/I] & $1.7(1.5-1.9)$ & $1.7(1.4-1.8)$ & $1.8(1.5-2.0)$ & 0.33 \\
\hline Triglycerides / HDL-C ratio & $1.4(0.8-2.1)$ & $1.3(0.8-2.1)$ & $1.4(0.9-2.1)$ & 0.53
\end{tabular}

Laboratory results

\begin{tabular}{|c|c|c|c|c|}
\hline Red Blood Cells [T/I] & $\begin{array}{l}4.8(4.6 \\
-5.2)\end{array}$ & $4.8(4.6-5.0)$ & $4.8(4.6-5.3)$ & 0.33 \\
\hline Hemoglobin $[\mathrm{g} / \mathrm{l}]$ & $\begin{array}{l}14.3(13.3- \\
15.2)\end{array}$ & $\begin{array}{l}14.3(12.8- \\
15.1)\end{array}$ & $\begin{array}{l}14.2(13.5- \\
15.2)\end{array}$ & 0.52 \\
\hline Hematocrit [\%] & $\begin{array}{l}42.2(39.2- \\
44.1)\end{array}$ & $\begin{array}{l}42.0(38.5- \\
44.1)\end{array}$ & $\begin{array}{l}42.7(39.5- \\
44.8)\end{array}$ & 0.41 \\
\hline $\begin{array}{l}\text { Mean Red Blood Cells Volume } \\
\text { [f]] }\end{array}$ & $\begin{array}{l}85.8(82.9- \\
88.2)\end{array}$ & $\begin{array}{l}85.8(83.3- \\
87.3)\end{array}$ & $\begin{array}{l}85.5(82.9- \\
87.9)\end{array}$ & 0.96 \\
\hline White Blood Cells [G/I] & $\begin{array}{l}6.3(5.5 \\
-7.3)\end{array}$ & $6.0(5.4-7.2)$ & $6.4(5.5-7.3)$ & 0.49 \\
\hline Platelets [G/I] & $\begin{array}{l}262.0(245.0- \\
308.0)\end{array}$ & $\begin{array}{l}269.0 \\
(245.0- \\
315.0)\end{array}$ & $\begin{array}{l}260.5(246.0- \\
305.0)\end{array}$ & 0.68 \\
\hline Mean Platelet Volume [f]] & $\left.\frac{10.6}{11.2}\right)$. & $\left.\frac{10.4}{10.7}\right)$ & $\frac{10.8}{11.5)} .(10.3-$ & $\underline{0.041}$ \\
\hline Platelet Distribution Width [\%] & $\frac{12.5}{14.2)}$. & $\frac{12.3}{12.8)}$. & $\frac{13.2}{14.9)}$. & $\underline{0.029}$ \\
\hline $\mathrm{HbA} 1 \mathrm{c}[\%]$ & $8.2(7.0-9.1)$ & $7.9(7.2-8.8)$ & $8.5(7.0-9.7)$ & 0.24 \\
\hline ALT [UI/I] & $\begin{array}{l}16.0(12.0- \\
20.0)\end{array}$ & $\begin{array}{l}15.0(11.0- \\
17.0)\end{array}$ & $\begin{array}{l}16.5(12.5- \\
24.5)\end{array}$ & 0.24 \\
\hline AST [UI/I] & $\begin{array}{l}17.0(15.0- \\
21.0)\end{array}$ & $\begin{array}{l}17.0(15.0- \\
21.0)\end{array}$ & $\begin{array}{l}17.0(15.0- \\
20.5)\end{array}$ & 0.70 \\
\hline Creatinine $[\mu \mathrm{mol} / \mathrm{L}]$ & 73.4 (67.2- & $\begin{array}{l}73.8 \text { (66.3- } \\
17 / 26\end{array}$ & $72.9(68.1-$ & 0.73 \\
\hline
\end{tabular}




\begin{tabular}{|c|c|c|c|c|}
\hline & $85.7)$ & 84.9) & 86.6) & \\
\hline $\mathrm{ACR}[\mathrm{mg} / \mathrm{g}]$ & $3.6(3.0-7.0)$ & $4.0(3.0-9.0)$ & $3.5(3.0-6.0)$ & 0.38 \\
\hline $\begin{array}{l}\text { Estimated Glucose Disposal } \\
\text { Rate }[\mathrm{mg} / \mathrm{kg} / \mathrm{min}]\end{array}$ & $9.2(8.0-10.3)$ & $\begin{array}{l}9.1(8.1- \\
10.4)\end{array}$ & $\begin{array}{l}9.3(7.8- \\
10.2)\end{array}$ & 0.59 \\
\hline Skin Autofluorescence [IU] & $2.1(1.8-2.4)$ & $2.0(1.8-2.2)$ & $2.1(1.9-2.5)$ & 0.35 \\
\hline MPV/PLT ratio & $\begin{array}{l}0.041(0.034- \\
0.044)\end{array}$ & $\begin{array}{l}0.039 \\
(0.031- \\
0.043)\end{array}$ & $\begin{array}{l}0.041(0.036- \\
0.045)\end{array}$ & 0.24 \\
\hline \multicolumn{5}{|c|}{ Activity during day of measurement } \\
\hline Time of physical activity [min] & $\begin{array}{l}20.0(0.0- \\
40.0)\end{array}$ & $\begin{array}{l}20.0(0.0- \\
50.0)\end{array}$ & $20.0(0.0-40.0)$ & 0.93 \\
\hline Number of cigarettes [n] & $0.0(0.0-2.0)$ & $0.0(0.0-0.0)$ & $0.0(0.0-4.0)$ & 0.52 \\
\hline Number of coffee cups [n] & $2.0(1.0-3.0)$ & $2.0(1.0-2.0)$ & $2.0(1.0-3.0)$ & 0.48 \\
\hline Mean glycemia $[\mathrm{mmol} / \mathrm{l}]$ & $7.5(6.7-8.8)$ & $7.7(6.7-8.9)$ & $7.2(6.8-8.0)$ & 0.50 \\
\hline SD of glycemia $[\mathrm{mmol} / \mathrm{l}]$ & $2.5(2.0-3.0$ & $2.6(2.0-3.5)$ & $2.5(2.0-2.9)$ & 0.25 \\
\hline Insulin/day (u) & $\begin{array}{l}38.1(30.5- \\
46.0)\end{array}$ & $\begin{array}{l}36.0(30.5- \\
44.5)\end{array}$ & $39.0(31.5-48.0)$ & 0.27 \\
\hline Carbohydrates/day (g) & $\begin{array}{l}15.3(11.8- \\
18.5)\end{array}$ & $\begin{array}{l}14.0(12.0- \\
17.5)\end{array}$ & $16.0(11.5-19.0)$ & 0.56 \\
\hline
\end{tabular}

Data presented as median (IQR) / n(\%).

ACR - Albumin to Creatinine Ratio, ALT - Alanine Transaminase, AST - Aspartate Transaminase, BMI Body Mass Index, HbA1c - Glycated Hemoglobin, HDL-C - High-Density Lipoprotein, LDL-C - LowDensity Lipoprotein, WHR - Waist-to-Hip Ratio

Table 2. Comparison of groups with and without brachial non-dipping pattern according to the Arteriograph 24 results. 


\begin{tabular}{|c|c|c|c|c|}
\hline & $\begin{array}{l}\text { All } \\
\text { participants }\end{array}$ & $\begin{array}{l}\text { SBP Br } \\
\text { dippers }\end{array}$ & $\begin{array}{l}\text { SBP Br non- } \\
\text { dippers }\end{array}$ & $\mathrm{p}$-value \\
\hline & $n=62(100 \%)$ & $\begin{array}{l}\mathrm{n}=37 \\
(57.7 \%)\end{array}$ & $\begin{array}{l}n=25 \\
(40.3 \%)\end{array}$ & \\
\hline \multicolumn{5}{|l|}{ General characteristics } \\
\hline Males n (\%) & $\underline{32}(\underline{51.6 \%})$. & $15(\underline{40.5 \%)}$. & $\underline{17(\underline{68.0 \%}) .}$ & $\underline{0.034}$ \\
\hline Age [years] & $\begin{array}{l}30.1(25.7- \\
37.0)\end{array}$ & $\begin{array}{l}30.0(26.3- \\
37.3)\end{array}$ & $\begin{array}{l}30.3(24.0- \\
36.4\end{array}$ & 0.38 \\
\hline Diabetes duration [years] & $\begin{array}{l}15.0(9.0- \\
20.0)\end{array}$ & $\begin{array}{l}16.0(9.0- \\
20.0)\end{array}$ & $\begin{array}{l}15.0(8.0- \\
18.0)\end{array}$ & 0.38 \\
\hline BMI $\left[\mathrm{kg} / \mathrm{m}^{2}\right]$ & $\begin{array}{l}24.8(22.7- \\
28.2)\end{array}$ & $\begin{array}{l}25.8(23.2- \\
28.4)\end{array}$ & $\begin{array}{l}23.8(21.5- \\
28.0)\end{array}$ & 0.28 \\
\hline WHR & $0.9(0.8-0.9)$ & $0.8(0.8-0.9)$ & $0.9(0.8-0.9)$ & 0.71 \\
\hline Family history for CVD n (\%) & $17(27.4 \%)$ & $10(27.0 \%)$ & $7(28.0 \%)$ & 0.93 \\
\hline Systolic blood pressure [mmHg] & $\begin{array}{l}123.0(120.0- \\
131.0)\end{array}$ & $\begin{array}{l}121.0(115.0- \\
130.0)\end{array}$ & $\begin{array}{l}123.0(120.0- \\
136.0)\end{array}$ & 0.22 \\
\hline Diastolic blood pressure [mmHg] & $\begin{array}{l}80.0(76.0- \\
86.0)\end{array}$ & $\begin{array}{l}82.0(76.0- \\
85.0)\end{array}$ & $\begin{array}{l}80.0(77.0- \\
87.0)\end{array}$ & 0.48 \\
\hline \multicolumn{5}{|l|}{ Lifestyle } \\
\hline Current smoker n (\%) & $15(24.2 \%)$ & $10(27.0 \%)$ & $5(20.0 \%)$ & 0.53 \\
\hline Packyears & $0.0(0.0-68.0)$ & $0.0(0.0-80.0)$ & $0.0(0.0-60.0)$ & 0.93 \\
\hline Sport activity [hours/week] & $2.4(0.0-6.0)$ & $2.0(0.0-6.0)$ & $3.3(0.0-6.0)$ & 0.76 \\
\hline Alcohol intake [units/week] & $1.0(0.0-2.0)$ & $1.0(0.0-1.0)$ & $2.0(0.0-3.0)$ & 0.050 \\
\hline Shift work n (\%) & $22(35.5 \%)$ & $13(35.1 \%)$ & $9(36.0 \%)$ & 0.94 \\
\hline Sleeping [hours/day] & $7.0(6.0-8.0)$ & $7.0(6.0-8.0)$ & $7.0(6.0-8.0)$ & 0.80 \\
\hline Physical work [hours/day] & $3.0(0.0-8.0)$ & $3.3(0.0-8.0)$ & $3.0(0.0-8.0)$ & 0.87 \\
\hline \multicolumn{5}{|l|}{ Complications } \\
\hline $\begin{array}{l}\text { At least one diabetic } \\
\text { complication } \mathrm{n}(\%)\end{array}$ & 34 (54.8\%) & $21(56.8 \%)$ & $13(52.0 \%)$ & 0.71 \\
\hline Diabetic retinopathy n (\%) & $12(19.4 \%)$ & $5(13.5 \%)$ & $7(28.0 \%)$ & 0.16 \\
\hline
\end{tabular}




\begin{tabular}{|c|c|c|c|c|}
\hline Diabetic nephropathy n (\%) & $2(3.2 \%)$ & $1(2.7 \%)$ & $1(4.0 \%)$ & 0.78 \\
\hline Diabetic neuropathy n (\%) & $28(45.2 \%)$ & $19(51.4 \%)$ & $9(36.0 \%)$ & 0.23 \\
\hline \multicolumn{5}{|l|}{ Treatment } \\
\hline Insulin pump n (\%) & $25(40.3 \%)$ & $14(37.8 \%)$ & $11(44.0 \%)$ & 0.75 \\
\hline $\begin{array}{l}\text { Daily insulin intake [insulin } \\
\text { units/day } / \mathrm{kg} \text { ] }\end{array}$ & $0.6(0.5-0.7)$ & $0.6(0.5-0.6)$ & $0.6(0.5-0.7)$ & 0.72 \\
\hline Metformin n (\%) & $6(9.7 \%)$ & $3(8.1 \%)$ & $3(12 \%)$ & 0.61 \\
\hline
\end{tabular}

\section{Lipid profile}

\begin{tabular}{|c|c|c|c|c|}
\hline Triglycerides [mmol/l] & $1.0(0.7-1.3)$ & $0.9(0.6-1.3$ & $1.0(0.8-1.4)$ & 0.39 \\
\hline Total cholesterol [mmol/l] & $4.6(4.2-5.1)$ & $4.6(4.2-5.1)$ & $4.6(4.2-5.0)$ & 0.70 \\
\hline LDL-C [[mmol/l] & $2.4(2.0-2.8)$ & $2.5(2.2-2.9)$ & $2.2(1.9-2.8)$ & 0.25 \\
\hline $\mathrm{HDL}-\mathrm{C}[\mathrm{mmol} / \mathrm{l}]$ & $1.7(1.5-1.9)$ & $1.7(1.5-1.9)$ & $1.8(1.4-1.9)$ & 0.76 \\
\hline Triglycerides / HDL-C ratio & $1.4(0.8-2.1)$ & $1.3(0.8-2.1)$ & $1.4(0.9-2.1)$ & 0.65 \\
\hline \multicolumn{5}{|l|}{ Laboratory results } \\
\hline Red Blood Cells [T/I] & $\begin{array}{l}4.8(4.6 \\
-5.2)\end{array}$ & $4.8(4.6-5.0)$ & $4.8(4.6-5.5)$ & 0.30 \\
\hline Hemoglobin [g/l] & $\begin{array}{l}14.3(13.3- \\
15.2)\end{array}$ & $\begin{array}{l}14.2(13.2- \\
15.1)\end{array}$ & $\begin{array}{l}14.3(13.5- \\
15.6)\end{array}$ & 0.32 \\
\hline Hematocrit [\%] & $\begin{array}{l}42.2(39.2- \\
44.1)\end{array}$ & $\begin{array}{l}42.1(38.7- \\
44.0)\end{array}$ & $\begin{array}{l}42.5(39.8- \\
45.5)\end{array}$ & 0.26 \\
\hline Mean Red Blood Cells Volume [fl] & $\begin{array}{l}85.8(82.9- \\
88.2)\end{array}$ & $\begin{array}{l}85.8(83.3- \\
87.3)\end{array}$ & $\begin{array}{l}85.8(82.9- \\
87.5)\end{array}$ & 1.00 \\
\hline White Blood Cells [G/I] & $\begin{array}{l}6.3(5.5 \\
-7.3)\end{array}$ & $6.3(5.5-7.4)$ & $6.3(5.5-6.9)$ & 0.95 \\
\hline Platelets [G/I] & $\begin{array}{l}262.0(245.0- \\
308.0)\end{array}$ & $\begin{array}{l}263.0(246.0- \\
314.0)\end{array}$ & $\begin{array}{l}259.0(230.0- \\
302.0)\end{array}$ & 0.45 \\
\hline Mean Platelet Volume [f] & $\begin{array}{l}10.6(10.1- \\
11.2)\end{array}$ & $\begin{array}{l}10.4(10.0- \\
10.9)\end{array}$ & $\begin{array}{l}10.7(10.3- \\
11.4)\end{array}$ & 0.11 \\
\hline
\end{tabular}

Platelet Distribution Width [\%] 


\begin{tabular}{|c|c|c|c|c|c|}
\hline & 14.2). & 13.4). & 15.1). & & \\
\hline $\mathrm{HbA1c}[\%]$ & $8.2(7.0-9.1)$ & $\begin{array}{l}7.9(7.2 \\
8.9)\end{array}$ & $8.5(7.0-9.9)$ & 0.24 & \\
\hline ALT [UI/I] & $\begin{array}{l}16.0(12.0- \\
20.0)\end{array}$ & $\begin{array}{l}15.0(13.0- \\
19.0)\end{array}$ & $\begin{array}{l}16.0(11.0- \\
24.0)\end{array}$ & 0.67 & \\
\hline AST [UI/I] & $\begin{array}{l}17.0(15.0- \\
21.0)\end{array}$ & $\begin{array}{l}17.0(15.0- \\
20.0)\end{array}$ & $\begin{array}{l}16.0(15.0- \\
21.0)\end{array}$ & 0.75 & \\
\hline Creatinine $[\mu \mathrm{mol} / \mathrm{L}]$ & $\begin{array}{l}73.4(67.2- \\
85.7)\end{array}$ & $\begin{array}{l}71.6(67.2- \\
80.4)\end{array}$ & $\begin{array}{l}75.1(70.7- \\
86.6)\end{array}$ & 0.25 & \\
\hline ACR $[\mathrm{mg} / \mathrm{g}]$ & $3.6(3.0-7.0)$ & $\begin{array}{l}3.2(3.0 \\
7.0)\end{array}$ & $5.0(3.0-7.0)$ & 0.93 & \\
\hline $\begin{array}{l}\text { Estimated Glucose Disposal Rate } \\
\text { [mg/kg/min] }\end{array}$ & $9.2(8.0-10.3)$ & $\begin{array}{l}9.4(8.1 \\
10.3)\end{array}$ & $8.8(8.0-10.1)$ & 0.38 & \\
\hline Skin Autofluorescence [IU] & $2.1(1.8-2.4)$ & $\begin{array}{l}2.1(1.9 \\
2.4)\end{array}$ & $2.0(1.7-2.3)$ & 0.50 & \\
\hline MPV/PLT ratio & $\begin{array}{l}0.041(0.034- \\
0.044)\end{array}$ & $\begin{array}{l}0.039(0.033- \\
0.043)\end{array}$ & $\begin{array}{l}0.041(0.036- \\
0.045)\end{array}$ & 0.24 & \\
\hline \multicolumn{6}{|l|}{ Activity during day of measurement } \\
\hline Time of physical activity [min] & $\begin{array}{l}20.0(0.0- \\
40.0)\end{array}$ & $\begin{array}{l}30.0(10.0- \\
40.0)\end{array}$ & $10.0(0.0-30.0)$ & & 0.09 \\
\hline Number of cigarettes [n] & $0.0(0.0-2.0)$ & $0.0(0.0-3.0)$ & $0.0(0.0-1.0)$ & & 0.89 \\
\hline Number of coffee cups [n] & $2.0(1.0-3.0)$ & $\begin{array}{l}2.0(1.0 \\
-3.0)\end{array}$ & $2.0(1.0-3.0)$ & & 0.50 \\
\hline Mean glycemia [mmol/l] & $7.5(6.7-8.8)$ & $7.4(6.8-8.0)$ & $7.6(6.5-9.0)$ & & 0.82 \\
\hline SD of glycemia [mmol/l] & $2.5(2.0-3.0)$ & $2.5(1.9-2.9)$ & $2.5(2.2-3.1)$ & & 0.26 \\
\hline Insulin/day (u) & $\begin{array}{l}38.1(30.5- \\
46.0)\end{array}$ & $\begin{array}{l}37.9(30.5- \\
44.9)\end{array}$ & $39.0(31.7-46.0)$ & & 0.79 \\
\hline Carbohydrates/day (g) & $\begin{array}{l}15.3(11.8- \\
18.5)\end{array}$ & $\begin{array}{l}15.0(12.8- \\
17.8)\end{array}$ & $16.8(11.0-20.0)$ & & 0.82 \\
\hline
\end{tabular}

Data presented as median (IQR) / $\mathrm{n}(\%)$.

ACR - Albumin to Creatinine Ratio, ALT - Alanine Transaminase, AST - Aspartate Transaminase, BMI Body Mass Index, HbA1c - Glycated Hemoglobin, HDL-C - High-Density Lipoprotein, LDL-C - LowDensity Lipoprotein, WHR - Waist-to-Hip Ratio,

Table 3. Participants without hypertension in 24-hour BP measurement. Comparison of dippers and nondippers. 


\begin{tabular}{|c|c|c|c|c|}
\hline & $\begin{array}{l}\text { All participants } \\
\mathrm{n}=24(100 \%)\end{array}$ & $\begin{array}{l}\text { SBP Ao dippers } \\
\mathrm{n}=13(54.2 \%)\end{array}$ & $\begin{array}{l}\text { SBP Ao non-dippers } \\
\mathrm{n}=11(45.8 \%)\end{array}$ & $\mathrm{p}$-value \\
\hline \multicolumn{5}{|l|}{ Laboratory results } \\
\hline Mean Platelet Volume [f]] & $\left.\frac{10.7}{11.3}\right)$. & $\frac{10.5}{10.7)}(10.0-$ & $11.0(10.5-11.6)$. & $\underline{0.026}$ \\
\hline $\begin{array}{l}\text { Platelet Distribution Width } \\
\text { [\%] }\end{array}$ & $\frac{12.5}{14.4)}(11.9-$ & $\frac{12.0}{12.6)}(11.7-$ & $\underline{14.0}(\underline{12.5-15.1})$. & $\underline{0.035}$ \\
\hline
\end{tabular}

Data presented as median (IQR) / n (\%).

\section{Figures}

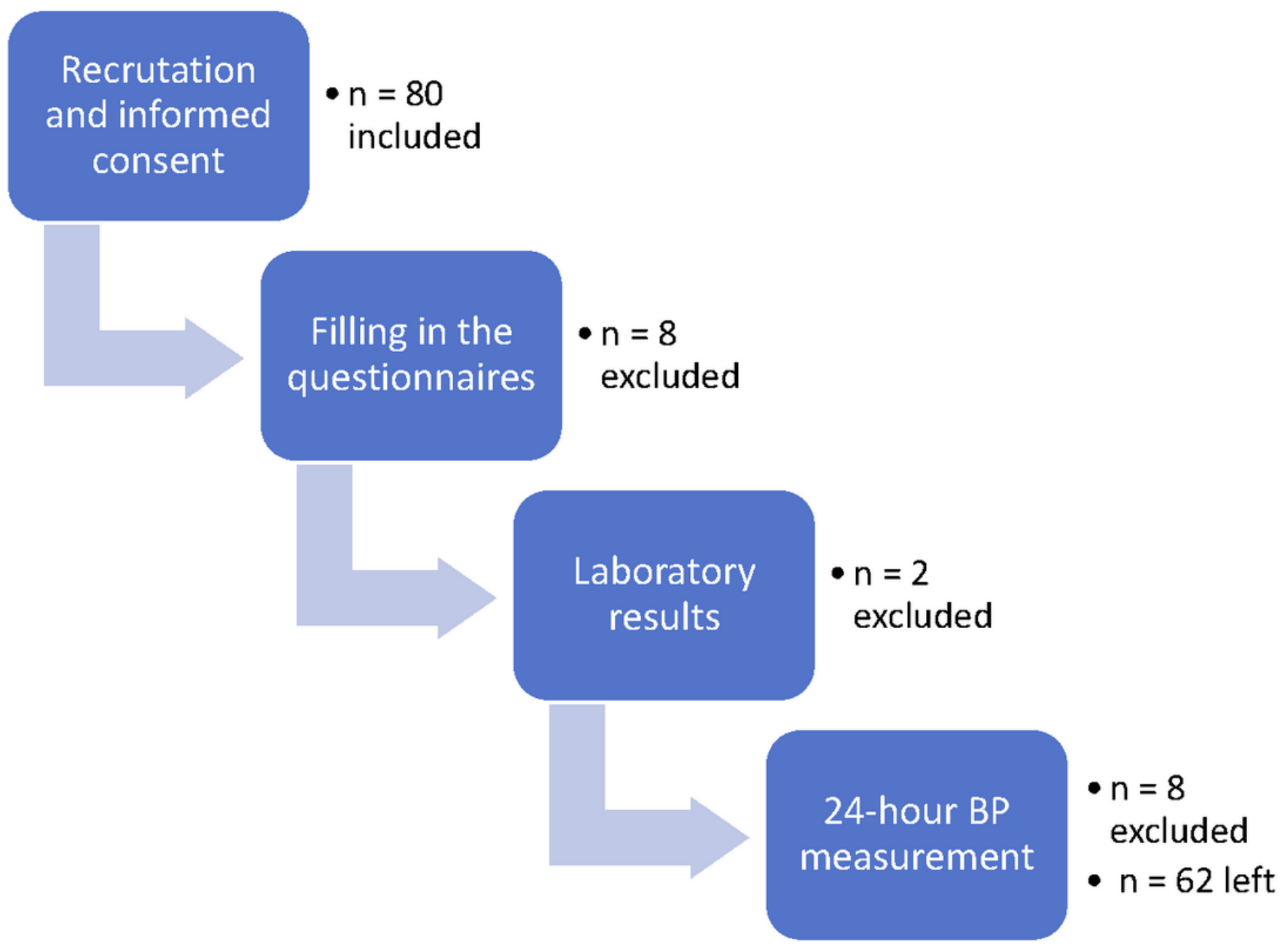

Figure 1

Flow diagram of the study and order of the procedures. BP - Blood pressure 


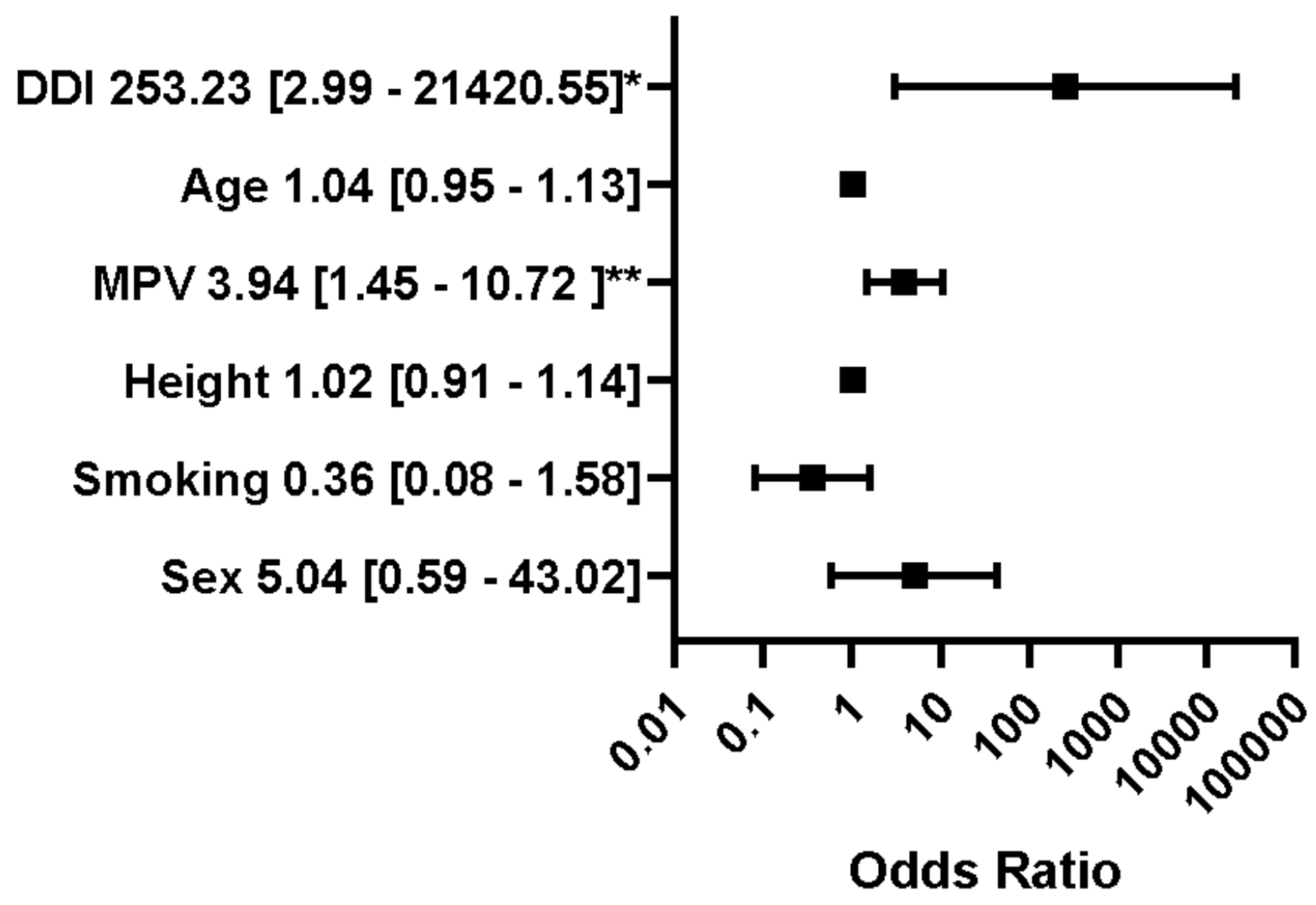

Figure 2

Multivariate logistic regression analysis. The dependent variable: the presence of central non-dipping pattern (coded one). The outcomes presented as a dependent variable (odds ratio, $95 \%$ confidence interval). *. significant at the 0.05 level **. significant at the 0.01 level MPV - mean platelet volume, DDI daily insulin intake 


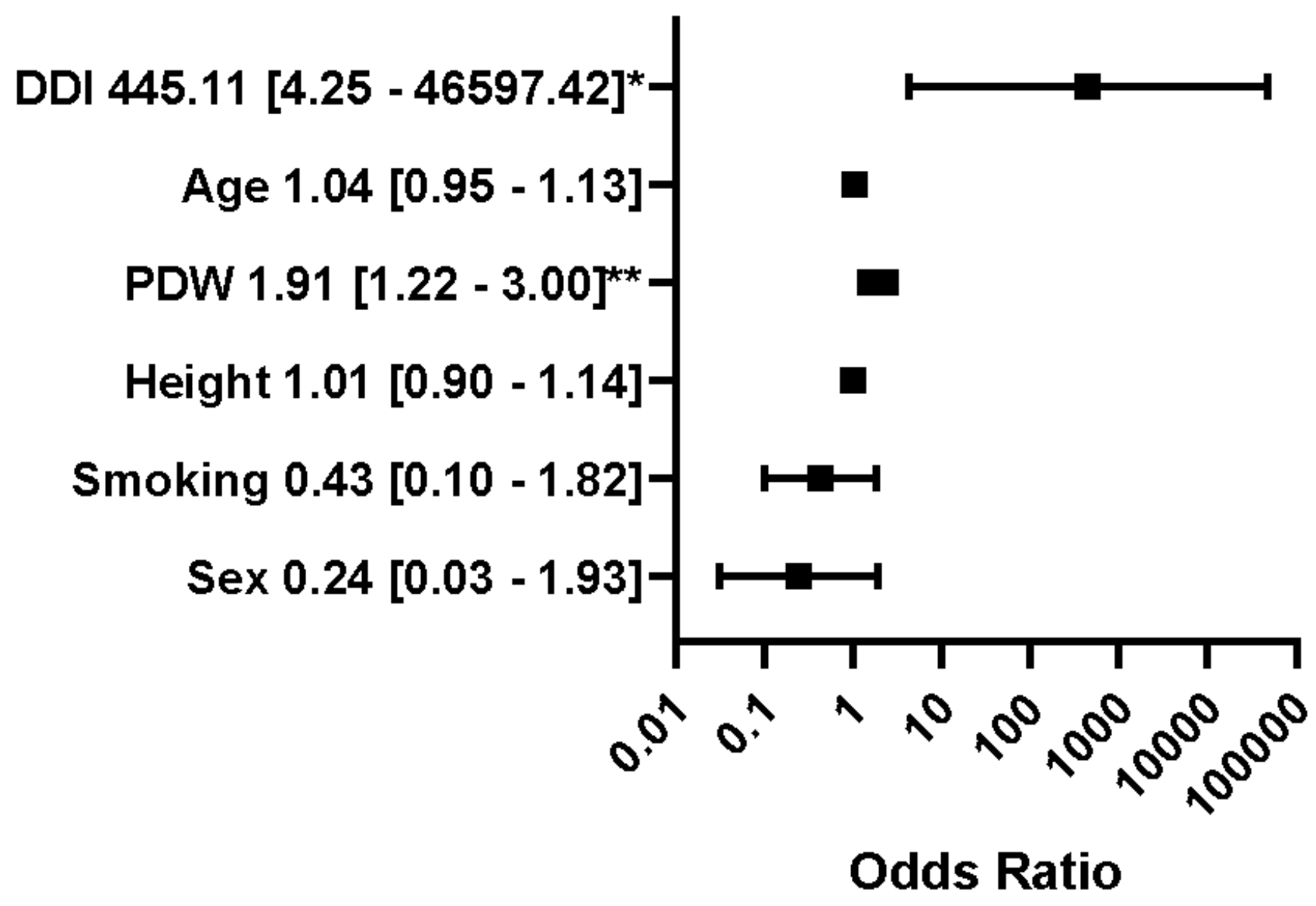

Figure 3

Multivariate logistic regression analysis. The dependent variable: the presence of central non-dipping pattern (coded one). The outcomes presented as a dependent variable (odds ratio, $95 \%$ confidence interval). *. significant at the 0.05 level **. significant at the 0.01 level PDW - platelet distribution width, DDI - daily insulin intake 


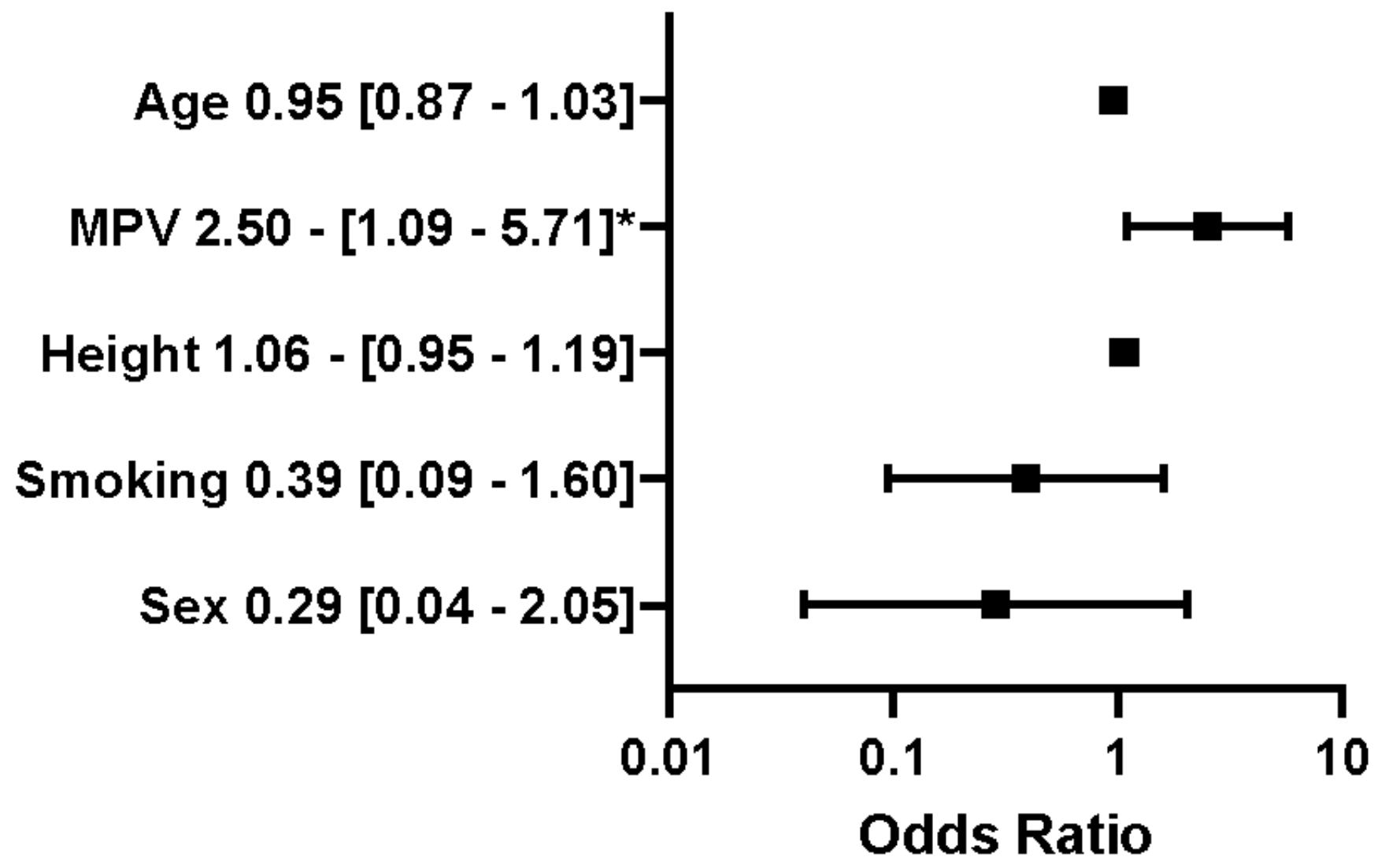

Figure 4

Multivariate logistic regression analysis. The dependent variable: the presence of brachial non-dipping pattern (coded one). The outcomes presented as a dependent variable (odds ratio, 95\% confidence interval). *. significant at the 0.05 level **. significant at the 0.01 level MPV - mean platelet volume, DDI daily insulin intake 


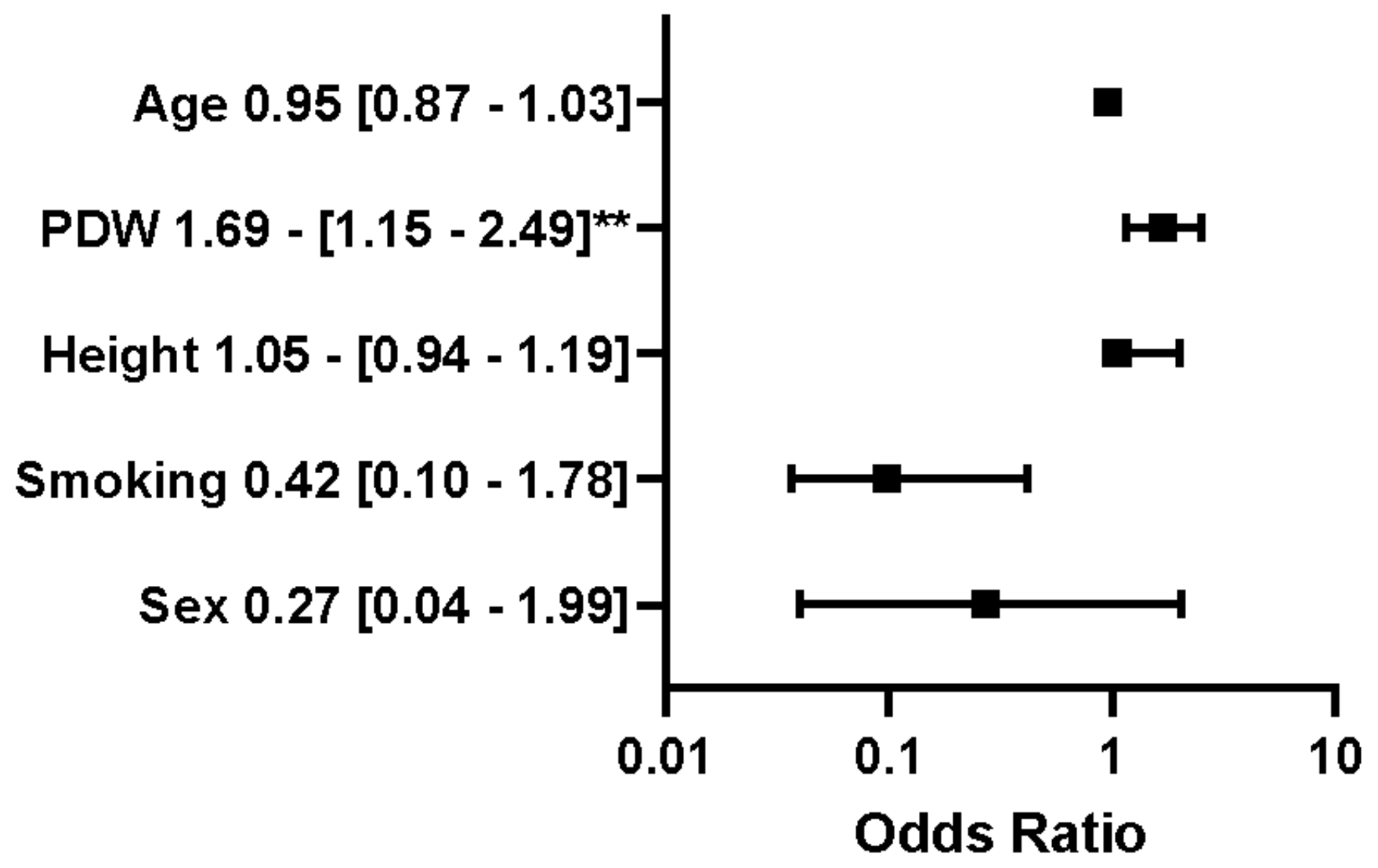

Figure 5

Multivariate logistic regression analysis. The dependent variable: the presence of brachial non-dipping pattern (coded one). The outcomes presented as a dependent variable (odds ratio, $95 \%$ confidence interval). *. significant at the 0.05 level **. significant at the 0.01 level PDW - platelet distribution width, DDI - daily insulin intake

\section{Supplementary Files}

This is a list of supplementary files associated with this preprint. Click to download.

- SupplementaryTable1univariateregression.docx 